This item was submitted to Loughborough's Research Repository by the author.

Items in Figshare are protected by copyright, with all rights reserved, unless otherwise indicated.

\title{
Discharge and suspended sediment time series as controls on fine sediment ingress into gravel river beds
}

PLEASE CITE THE PUBLISHED VERSION

https://doi.org/10.1016/j.catena.2018.10.001

\section{PUBLISHER}

(C) Elsevier

\section{VERSION}

AM (Accepted Manuscript)

\section{PUBLISHER STATEMENT}

This paper was accepted for publication in the journal Catena and the definitive published version is available at https://doi.org/10.1016/j.catena.2018.10.001

\section{LICENCE}

CC BY-NC-ND 4.0

\section{REPOSITORY RECORD}

Mathers, Kate L., Stephen Rice, and Paul Wood. 2019. "Discharge and Suspended Sediment Time Series as Controls on Fine Sediment Ingress into Gravel River Beds". figshare. https://hdl.handle.net/2134/35639. 
1 Working title: Discharge and suspended sediment time series as controls on fine 2 sediment ingress into gravel river beds

3

4

5 Kate L. Mathers ${ }^{1 *}$, Stephen P. Rice ${ }^{2}$ and Paul J. Wood ${ }^{2}$

6

7 1. Eawag, Department of Surface Waters Research and Management,

86047 Kastanienbaum, Switzerland

9 2. Geography and Environment, Centre for Hydrological and Ecosystem Science, 10 Loughborough University, Loughborough, UK

\section{Author for Correspondence}

12 Kate Mathers

13 Eawag,

14 Department of Surface Waters Research and Management,

156047 Kastanienbaum, Switzerland

16 Email:- kate.mathers@eawag.ch

17

18

19

20

21

22

23

24

25

26

27

28

29

30

31

32

33

34

35 
Working title: Discharge and suspended sediment time series as controls on

Mathers, K.L, Rice, S.P. and Wood, P.J.

40

\section{Abstract}

Fine sediment availability and channel hydraulics are two of the primary controls on the ingress of fine sediment into gravel river beds. A novel dataset consisting of fine sediment ingress measurements coupled with high-resolution turbidity and discharge time series, was analysed to investigate relations between ingress, discharge and turbidity. Discharge and turbidity demonstrated a weak association with each other, and their relations with fine sediment ingress were relatively weak. An alternative, but widely applied 'redundancy' approach was investigated that focused on key metrics, or facets, of the discharge and turbidity time series and their association with fine sediment ingress. Principal component analysis was used to distil the most important facets driving variation in the discharge and turbidity datasets and these were then used as independent variables in regression models with sediment ingress as the dependent variable. These models accounted for a larger amount of the statistical variation in sediment ingress over time than discharge and turbidity time series. Facets of the turbidity time series were found to be the most effective explanatory variables. The results suggest that this approach could be valuable and justify its application and testing across a range of river types in different hydrological and sedimentary settings. Application of this method could improve our generic understanding of what controls ingress at larger spatial and temporal scales and therefore complements process-based approaches, which is vital for the development of fine sediment management strategies.

62

Keywords: sedimentation, redundancy approach, principal component analysis, facets, management. 
71 Excessive sedimentation within aquatic ecosystems is a global concern and can have detrimental consequences for all aspects of lotic ecosystem health (Heppell et al., 2009; Relyea et al., 2012; Naden et al., 2016). The deleterious effects of fine sediment on biota are well documented and are predominantly associated with sediment deposition onto, and ingress into, the river bed (Kemp et al., 2011; Jones et al., 2012a, b; 2014). Effective management of fine sediment loading therefore requires understanding of the relations between deposition and ingress and their key drivers, including sediment supply and water discharge (Diplas and Parker, 1992) at scales that are relevant to catchment management.

Fine sediment deposition into a framework of gravel clasts involves a complex set of processes. Ingress rates are related to several factors including local hydraulics (Buffington and Montgomery, 1999), vertical and lateral interstitial exchange (Mathers and Wood, 2016), the relative size of the infiltrating and framework particles (Gibson et al., 2009), the concentration of suspended sediment and the settling flux (Brunke, 1999), and sediment transport capacity (Naden et al., 2016). Local hydraulic characteristics such as shear stress, flow velocity and Froude number have been associated with fine sediment accumulation, but studies often disagree regarding the gross influence of these hydraulic parameters (Petticrew et al., 2007). Beschta and Jackson (1979) found that the Froude number was positively associated with ingress, whilst Einstein (1968) and Carling (1984) found no relationship with flow parameters. It is possible that local hydraulic influences differ as a function of the dominant hydrological process. In low energy, slow-flowing waters, fine sediment ingress rates can be high because deposition rates are enhanced (Wood and Armitage, 1999), whereas in high-velocity areas sediment supply can be accentuated, enhancing the availability of fine sediment for subsequent infiltration (Frostick et al., 1984). As such, the availability of fines, as regulated by supply, transport capacity and, potentially biotic effects (e.g. Rice et al., 2016) may dominate the rate of infiltration irrespective of local hydraulics and framework size (Carling and McCahon, 1987; Sear, 1993).

100 Despite an enhanced understanding of the small-scale processes that control fine sediment infiltration (grains to patches; seconds to minutes) there is still no simple 
predictive model of fine sediment ingress than can be applied at large spatial and temporal scales. Moreover, despite a general understanding that both local hydraulics and sediment supply respond to hydrological processes that occur over longer, monthly-annual timescales, few studies have investigated the relations, over longer timescales, between variations in fine sediment ingress, suspended sediment concentrations and river discharge. This is unfortunate because there is a global need to set river management targets that maintain healthy rates of fine sediment delivery, deposition and transport (Collins et al., 2011) and gaining an understanding of the factors that influence fine sediment ingress on such time-scales is vital for developing relevant management strategies (e.g. Naden et al., 2016).

112 Both field and laboratory studies have identified fine sediment availability as a key determinant of ingress rates (Petts, 1984; Sear, 1993), with positive associations between suspended sediment concentration and ingress (Beschta and Jackson, 1979; Carling, 1984; Carling and McCahon, 1987). In general, fine sediment ingress rates are greatest during flood events when sediment transport rates are high and sediment is made available by scouring from pools and sub-armour deposits or is recruited to the channel via overland flow and other processes, including river bank collapse (Beschta et al., 1981; Sear, 1993; Petticrew et al., 2007). However, there is an apparent absence of studies which simultaneously investigate the relationship between flow, sediment supply and deposition to assess the potential explanatory power of different facets of these regimes (Wohl et al., 2015). Direct data on sediment transport and subsequent deposition is severely limited relative to river

124 discharge and there is a need for more high resolution and long term suspended 125 sediment data in order to characterise the magnitude, frequency, duration, timing and rate of change in suspended sediment levels (sensu Richter et al., 1996; Poff et al., 1997). Seeking greater understanding of the relations between the drivers and rates of fine sediment ingress over monthly-annual timescales is therefore valuable and consistent with Wohl et al.'s (2015) argument that the fine sediment regime can be managed through consideration of gross water and sediment balances.

131 In this regard, it is possible that ecohydrological approaches, which utilise a 132 redundancy' methodology to associate key elements of hydrological time series with 133 measurements of ecological health, may be useful (Richter et al., 1996; Olden and 
134 Poff, 2003). The purpose of such research has been to determine the ecologically

135 relevant components or 'facets' of discharge time series (duration, timing, frequency,

136 magnitude, rate of change in flow events; Richter et al., 1996; 1997; Poff et al., 1997)

137 that support ecologically healthy rivers, thereby facilitating the design of

138 'environmental flows' (Acreman and Ferguson, 2009; Wharfe et al., 2014; Mustonen

139 et al., 2016). Natural variability in stream processes is vital in maintaining diverse

140 and healthy systems (Arthington et al., 2006) and these facets, rather than single

141 simplistic metrics of a dynamic time series, are more appropriate for setting

142 management targets (Richter et al., 1997). Given the plethora of indices that can be

143 obtained from time series data (Poff, 1996), researchers must select which and how

144 many indices are relevant to use for modelling purposes, particularly when many are

145 inter-correlated (Olden and Poff, 2003).

147 Principal component analysis, a well-established multivariate technique, enables

148 several variables that are inter-correlated to be analysed for the degree of similarity

149 they characterise and subsequently transformed into a number of uncorrelated axes

150 (variables) called 'principal components' which represent linear combinations of the

151 original variables (Abdi and Williams, 2010). By identifying a reduced set of indices

152 that represent the degree of variability in the time series, annual river management

153 targets can be identified using a comprehensive statistical characterisation of

154 relevant regime characteristics (Richter et al., 1997). This is an explicitly empirical

155 method that requires careful application to avoid rejecting variables that are

156 important, but which are not principal drivers of statistical variability (Monk et al.,

157 2007). The method has been widely used beyond its original applications with flow

158 discharge time series; for example to establish associations between stream

159 temperature variability and instream communities (Jackson et al., 2007; Olden and

160 Naiman, 2010; White et al., 2017), to group relevant instream geomorphic

161 parameters for hydrological and ecological models (Singh et al., 2009; Faller et al.,

162 2016) and to identify geographical properties associated with landslide susceptibility

163 (Komac, 2006). At the core of this paper is an application of this methodology to fine

164 sediment ingress. It is motivated by a conviction that the design and implementation

165 of strategies that aim to manage levels of fine sediment storage in rivers would

166 benefit from a better understanding of how facets of flow and sediment regimes

167 relate to ingress rates. 
This paper utilises novel measurements of fine sediment ingress collected over several months. These data were used with time series of discharge and turbidity, where the latter is shown to be representative of fine sediment availability, to identify key drivers of sediment ingress using the ecohydrological 'redundancy' approach. This analysis reveals the exploratory power of facets of the discharge and turbidity regimes as predictors of fine sediment ingress into riverbeds and seeks to establish the potential of employing simple empirical models, at temporal and spatial scales relevant to catchment management, using variables that are easily collected in the field.

A two-stage approach was employed:

i) Classification of hydrological and turbidity time series into a small subset of indices that effectively characterise the dominant components (facets) of the series via a principal component analysis and redundancy reduction methodology (sensu Olden and Poff, 2003).

ii) Examination of the dominant facets of turbidity and discharge that influence sediment ingress using correlation matrices and the development of linear regression models using the principal component sample scores.

\section{Material and Methods}

\subsection{Study Sites}

188 Data was collected from two lowland rivers in Rutland, UK; the River Gwash (52 $38^{\prime}$ $\left.189 \mathrm{~N}, 00^{\circ} 44^{\prime} \mathrm{W}\right)$ and the River Chater ( $\left.52^{\circ} 37^{\prime} \mathrm{N}, 00^{\circ} 44^{\prime} \mathrm{W}\right)$. At the sites where measurements were made, the rivers are broadly comparable in physical characteristics (channel size, water chemistry, altitude and geology). The two sites are only $2.6 \mathrm{~km}$ apart geographically and therefore experienced similar synoptic meteorology and hydrological regimes. Close to the catchment outlet, mean flow is

$1940.18 \mathrm{~m}^{3} \mathrm{~s}^{-1}$ and $\mathrm{Q}_{10}\left(90^{\text {th }}\right.$ percentile) flow is $0.449 \mathrm{~m}^{3} \mathrm{~s}^{-1}$ for the River Chater. For the 195 river Gwash mean flow is $0.52 \mathrm{~m}^{3} \mathrm{~s}^{-1}$ and $Q_{10}$ flow is $1.16 \mathrm{~m}^{3} \mathrm{~s}^{-1}$ (NRFA, 2017).

196 Catchment geology is dominated by Jurassic mudstones and sandstones (British 197 Geological Survey, 2008) with both field sites located adjacent to arable farmland.

198 Surface and subsurface bed material consisted of mixed cobbles and gravel (Table 199 1). Invasive signal crayfish, Pacifastacus leniusculus (Dana), are present in high 200 abundances in the River Gwash but historic routine sampling by the Environment 
201 Agency of England and Wales and contemporary sampling during the study period 202 by the author has not recorded any individuals in the River Chater. Previous work 203 has suggested that signal crayfish are significant biogeomorphic agents capable of mobilising fine sediment (Harvey et al., 2014; Rice et al., 2014; 2016; Cooper et al., 2016) although this was not an explicit consideration in the research reported here.

\subsection{Discharge data}

208 Hydrological variability during the sampling period was analysed using data collected from local Environment Agency gauging stations on the River Chater (Fosters

210 Bridge; 52 $38^{\prime} \mathrm{N}, 00^{\circ} 35^{\prime} \mathrm{W}$ ) and River Gwash (Manton; 52 38'N, 00 42' W) at 15-

211 minute resolution. Discharge data $\left(\mathrm{m}^{3} \mathrm{~s}^{-1}\right)$ were converted to hourly averages to

212 facilitate the identification of marked differences in the series including known

213 hydrological events (floods or low flows; Figure 1a). The majority of the study period 214 consisted of baseflow conditions punctuated by flashy high flow events.

215 As the gauge sites were $2.9 \mathrm{~km}$ and $12.4 \mathrm{~km}$ downstream of the field sites on the 216 River Gwash and River Chater respectively, discharge values at the gauge site were 217 scaled based on the catchment drainage area of the sample site relative to the 218 gauge location.

\subsection{Turbidity data}

221 Turbidity was monitored at a 5-minute resolution using two turbidity sensors: an

222 Eureka 2 Manta sonde fitted with a self-wiping turbidity sensor (International

223 Organisation for Standardisation (ISO) 7027; 0-3000 NTU, quoted error $\pm 1 \%$ ) was

224 deployed at Brooke on the R. Gwash and a Seametrics, Instrumentation Northwest 225 Inc. (INW) self-wiping Turbo sensor (0-3000 NTU, quoted error $\pm 2 \%$ ) was deployed 226 at Ridlington on the R. Chater. Both sensors were independently calibrated before 227 deployment using the same turbidity standards. They were mounted horizontally $2280.1 \mathrm{~m}$ above the river bed with the sensors approximately $0.3 \mathrm{~m}$ from the left bank. 229 Recording errors during the study were intermittent. Where single measurements 230 were missing, they were interpolated using a local average of the previous and 231 subsequent record. Where sections of data were in error or missing because of 232 biofouling or data-logging problems, gaps were left in the time series. Datasets ran 233 from 18th June 2015 to $24^{\text {th }}$ September 2015 (98 days) with 12.0 and 18.1 days 234 removed due to recording errors at Ridlington and Brooke, respectively (Figure 1b). 
235 The continuous measurements of turbidity are used here as a surrogate of suspended mineral sediment concentration (SSC), and therefore of fine sediment availability for ingress. Turbidity is used as an independent variable because it is a measure of fine sediment availability that is easily and more readily measured then SSC, therefore representing a more widely available parameter. The use of turbidity as a surrogate for SSC should, however, be undertaken recognising that turbidity measurements are sensitive to the physical characteristics of suspended mineral sediments (colour, size, shape) and the presence of other suspended materials, including organic detritus (Bilotta and Brazier, 2008). To confirm the validity of the turbidity data as a representation of SSC, 93 and 206 water samples were collected from Ridlington and Brooke respectively, at baseflow through to storm flow conditions. Samples were collected using an ISCO 3700 automated water sampler fitted with a stage-activated trigger that drew water up from an inlet hose located immediately adjacent to the turbidity sensor. Samples were filtered using Whatman $0.7 \mu \mathrm{m}$ glass microfiber filters and analysed for percent organic matter and carbonate content through Loss-On-Ignition (LOI; Dean, 1974). The average organic component of samples was high at Brooke $(21.5 \%, \mathrm{SD}=5.36 \%)$ and Ridlington $(26.31 \%$, SD $=7.77 \%)$ so SSC was calculated using only the mineral mass. The correlation between mineral SSC values and measured turbidity was significant $(r=$ 0.92, $p<0.001)$ and demonstrated a strong linear fit $\left(R^{2}=0.86\right.$; Figure $\left.S 1\right)$. The continuous records of turbidity are therefore used as pragmatic surrogates for SSC and turbidity data (NTU) throughout the subsequent analysis.

\section{$257 \quad 2.4$ Fine sediment ingress}

258 At each site, sediment traps were installed that measured the mass of fine sediment ingress over 14-day deployment periods. Each trap comprised a PVC cylinder (diameter $65 \mathrm{~mm}$, height $200 \mathrm{~mm}$ ) perforated with twelve horizontal holes (diameter $6 \mathrm{~mm}$ ) to permit both horizontal and vertical exchange of flow and fine sediments (Mathers and Wood, 2016). All cylinders were filled with a prewashed gravel framework collected from each of the respective sample sites, truncated to exclude grains finer than $8 \mathrm{~mm}$ and enclosed in a net bag $(7 \mathrm{~mm}$ aperture). Use of the local gravel framework negates the potential influence that differing framework matrices have on ingress rates (Petticrew et al., 2007). Cylinders were inserted into the river bed by placing the PVC cylinders onto a steel pipe (35 $\mathrm{mm}$ diameter) that was then 
driven into the bed sediments and subsequently moved from side to side until a sufficient sized hole was formed. Cylinders were inserted flush with the sediment surface to a depth of $200 \mathrm{~mm}$ (Figure 2). Cylinders were left in-situ for the entire sampling campaign, but every 14 days the gravel netting bag was removed and replaced with a bag of clean gravel, providing a constant record of sediment accumulation at a 14-day resolution. At the end of each 14-day sampling period, the net bag (containing the gravel clasts) was carefully lifted out and immediately placed in a plastic bag to be processed in the laboratory with any loss of fine sediment being minimal. Negligible fine sediment was observed diffusing into the water column during extraction with fine material being held in the interstitial spaces of the gravels. Sediment traps were installed from $18^{\text {th }}$ June to $24^{\text {th }}$ September 2015 , providing a record of 98 days that consisted of seven 14-day sample sets (referred to as B1 - B7 for the Gwash site and R1 - R7 for the Chater site).

Three riffle sites were examined at Brooke and two at Ridlington (only one site was considered before $2^{\text {nd }}$ July 2015). At each riffle, four cylinders were installed providing a total of 12 replicates at Brooke and eight at Ridlington (four until $2^{\text {nd }}$ July for the first three 14-day sample sets). Cylinders were evenly spaced across the riffle unit (head through to tail) because fine sediment accumulation can vary as a function of longitudinal hydraulic gradients (Mathers and Wood, 2016). In total, 105 and 57 samples were extracted from Brooke and Ridlington respectively (a total of three cylinders could not be retrieved at both sites during the campaign). In the laboratory, the contents of the cylinder samples were passed through 4 and 2 $\mathrm{mm}$ sieves to remove the framework substrate and left to settle in a container. Fine sediment samples $(<2 \mathrm{~mm})$ were oven dried at $60^{\circ} \mathrm{C}$ until a constant weight was recorded. Samples were gently disaggregated, passed through a sieve nest (1000 $\mu \mathrm{m}$ and $125 \mu \mathrm{m}$ ) and each fraction weighed to determine the grain size distribution in

294 four grain size categories (total mass $<2000 \mu \mathrm{m}, 1000-2000 \mu \mathrm{m}, 125-1000 \mu \mathrm{m}$; $<125 \mu \mathrm{m})$. These separate grain size fractions were examined because the rate of fine sediment ingress is inherently associated with site-specific size ratios of infiltrating particles to framework gravels (Frings et al., 2008). The total mass of material < $2000 \mu \mathrm{m}$ collected in each 14-day sampling period for Brooke and

299 Ridlington is shown in Figure 1c 
2.5 Identification of time series facets via the redundancy approach

Spearman's rank correlation coefficients were calculated for hourly averaged flow and turbidity time series to establish whether there was any simple association between the two datasets. Preliminary analysis indicated that discharge values differed by site and so prior to subsequent analysis, flow data were scaled to Zscores to enable comparison across sites. 23 turbidity and 14 flow indices (see Table 2 for definitions) were calculated for each 14-day sampling period at Ridlington and Brooke. Indices were based on four facets of the two regimes: (i) magnitude - the quantity measured at a sampling point at a given time including minimum and maximum; (ii) frequency - how often the time series moved above a given magnitude; (iii) duration - the period of time over a specific threshold; and (iv) rate of change - how quickly the time series changes from one magnitude to another (Richter et al., 1996; Poff et al., 1997). Previous applications of Richter's (1997) methodology have focussed on characterising hydrological series for the purpose of identifying ecohydrological associations over multiple years, so the most relevant indices were adapted for the shorter timeseries used here (Richter et al., 1997; Olden and Poff, 2003; Monk et al., 2007). In addition, a number of indices were calculated that aimed to characterise the potential effect of biotic diurnal bioturbation (by crayfish) on the turbidity series (cf Rice et al., 2014; 2016): average night turbidity - AVNt; average day turbidity - AVDt; difference in day - night turbidity DDNt; and periodicity - PERt. Night was employed as a fixed time window (18:006:00; Rice et al., 2014).

Both hydrological and turbidity indices were analysed using principal component analysis (PCA) to identify redundant interrelated indices whilst retaining the major sources of statistical variation (Jolliffe, 1986). A series of PCAs were undertaken on turbidity and hydrological data in isolation and in combination using the 'prcomp' function in $\mathrm{R}$ version 3.2.2. PCAs were conducted to identify the dominant indices

327 following the PCA redundancy reduction approach outlined by Olden and Poff 328 (2003). Previous research employing this approach has typically utilized a maximum of six indices to sufficiently characterise the regimes (Monk et al., 2007; Belmar et al., 2013; Worrall et al., 2014) and consequently the six indices with the highest loadings on the first two principal component (PC) axes were identified for each set of variables (turbidity, hydrological and combined hydrological and turbidity). 
333 Following Olden and Poff (2003), the number of indices selected from each axis was 334 proportional to the variance explained by each PC relative to the others. For 335 example, based on the turbidity data, the first PC explained $48.4 \%$ of the total $68.5 \%$ 336 of the variance explained by the two significant components, resulting in four indices 337 being selected from PC1 and two from PC2. Highly correlated variables, with 338 Pearson's $r$ values greater than 0.95 , were considered redundant and removed to 339 retain six indices that effectively characterised statistical variability whilst minimising 340 collinearity (Monk et al., 2006).

\subsection{Relationship between turbidity, discharge and fine sediment ingress}

342 To examine the relationship between standardised discharge, turbidity and mass of 343 ingress, Spearman's rank correlation matrices were constructed for all 37 indices 344 and four ingress size categories. This enabled determination of the relative association of individual components of turbidity and discharge with sediment ingress. To assess the association of multiple facets of turbidity and discharge with ingress, the PC components (sample axis scores) resulting from the reduced set of variables in each dataset were used as independent variables to develop multiple linear regression models. In these models the dependent variables were mass of infiltrated sediment in each grain size fraction and the independent variables were PC components (axes scores). PC components with eigenvalues $>1$ were considered for inclusion in each model, and stepwise selection using the 'stepAIC' function in the 'MASS' package was used to select the best combination of variables

354 (Venables and Ripley, 2002). As a result of the removal of highly correlated and redundant variables through PCA selection and the subsequent compartmentalisation of the data to reduce its dimensionality, overfitting of models was minimal. This approach generated models using (1) discharge PC components,

358 (2) turbidity PC components or (3) discharge and turbidity PC components together, 359 to predict each of the grain size mass fractions. This enabled an evaluation of the 360 relative contribution to the explanatory power exerted by each driver (discharge or turbidity) independently and combined on the mass of sediment ingress by size fraction. To assess whether the turbidity or discharge regimes differed by site or time as a function of any facets of the series (e.g. magnitude and duration), a Generalised Linear Model (GLM) was fitted to the PC component scores using the ' $g / m$ ' function 
in the 'stats' package with a Gaussian error distribution. All statistical tests were conducted in the $\mathrm{R}$ environment (R Development Core Team, 2017).

\section{Results}

\subsection{Selection of turbidity and discharge variables}

When PCA was employed to determine which turbidity and hydrological indices were most influential in characterising the dominant sources of variability, the percentage of variance explained ranged from $87.07 \%$ for the combined variables (turbidity and hydrology together) through to $98.18 \%$ for the reduced number of hydrological indices (Table 3). Turbidity indices demonstrated the greatest variability compared to hydrological indices, with less variance being explained on the first axis in both instances for the full and reduced number of indices.

Using the PCA selection procedure for the turbidity variables, three indices were identified that represented magnitude of turbidity (median, average night and average difference in day and night turbidity values), two that represented the duration of turbidity events (duration over 10 NTU and duration over 100 NTU) and one that characterised the rate of change in turbidity (number of rises in the turbidity series; Figure 3a). Within the subset of six hydrological variables identified, the majority represented magnitude of discharge (minimum, average and standard deviation of discharge), two characterised the duration of discharge events above or below a threshold (duration under 0.1 scores, and duration over 14 day average discharge)and one characterised the rate of change in the discharge regime (number of rises in discharge series; Figure 3b). When both environmental factors (turbidity and hydrology) were considered together, turbidity accounted for a larger proportion of variance with four dominant turbidity indices and two hydrological indices

391 identified. Magnitude characteristics of the time series were the primary source of 392 variability (median discharge, standard deviation in discharge, median turbidity, maximum turbidity and average turbidity) and the remaining two indices represented

394 the duration of low magnitude events (duration under -0.1 discharge scores and 395 duration under 10 NTU; Figure 3c).

\subsection{Turbidity and discharge regimes characterisation}


397 Examination of the sample sites on the ordination plots and via general linear

398 regression of the first two PC axes scores, indicated that both sites were similar in

399 character regardless of the presence of crayfish (Figure 3; $p>0.05$ in both GLM

400 models). Despite this, Ridlington exhibited greater variation in turbidity over time, 401 with the majority of Brooke sites forming a cluster at the centre of the plot. Three 402 turbidity series represent extreme outliers, with Ridlington sample set one (R1) being 403 strongly associated with higher than average median turbidity, Ridlington set six (R6) 404 by average night turbidity values and duration over 100 NTU and Brooke set one 405 (B1) by difference in day and night turbidity. The dominant vectors of variation are 406 associated with the duration of events over 10 NTU and difference in day versus 407 night turbidity.

408 Discharge exhibited greater variability, with a wide spread of sites over time: the 409 majority of sites were heavily loaded on PC1, which was associated with low flow 410 conditions (Figure 3). Time periods in which baseflow conditions were dominant (e.g. 411 B2, R1, R4, B4) plot to the right of the ordination and those with high flow events plot 412 to the left (e.g. R6, R5, B3). When hydrological and turbidity variations were 413 considered in combination, sites plotted consistently together (Figure 3c). The 414 dominant vectors of variation were associated with low flow periods (duration under 4150.1 discharge scores and standard deviation of discharge) with two outliers that were 416 strongly influenced by turbidity (median turbidity -Ridlington set one, R1 and 417 maximum turbidity - Ridlington set two, R2).

\subsection{Discharge, turbidity and fine sediment ingress associations}

419 Discharge and turbidity time series (hourly averaged data) yielded weak associations 420 at both sites (Brooke $r_{s}=0.040 ; p<0.05$; Ridlington $\left.r_{s}=0.211 ; p<0.001\right)$. However, 421 moderate associations $\left(r_{s}>0.5\right)$ were apparent between some turbidity and 422 discharge indices (Table 4). 16 out of 23 discharge variables were associated with 423 the magnitude of the turbidity regime (i.e. maximum, minimum, range and standard 424 deviation of turbidity) and 11 of these associations were significant $(p<0.05$; Table 425 4). Of the remaining correlations, four were characterised by duration (three of which 426 were significant), and two with frequency of turbidity events (both of which were 427 significant). Duration of discharge was the main facets of the regime associated with 428 turbidity events, with 14 discharge variables demonstrating moderate relations with 
429 turbidity (12 of which were significant), followed by magnitude of discharge (seven

430 variables) and frequency of discharge events (two variables). The strongest

431 correlation was between the duration over the 14-day average discharge (D14AVd)

432 and the number of peaks over 100 NTU (NP100t; Table 4). Duration over the 14 day-

433 averaged discharge (D14AVd) was most strongly associated with turbidity

434 parameters.

435 In contrast, discharge and turbidity indices yielded weak associations with the mass

436 of sediment that infiltrated into traps (Table 5). Only three turbidity indices and one

437 discharge index had a moderate correlation $\left(r_{s}>0.5\right)$ with any of the different size

438 fractions of deposited sediment. The strongest correlation was between duration of

439 discharge over the 14-day average (D14AVd) and mass of fines in the size fraction

$440125-1000 \mu \mathrm{m}\left(r_{s}=0.617 ; p \leq 0.05\right)$. Grains in the size fraction 1000-2000 $\mu \mathrm{m}$

441 displayed the strongest correlation with turbidity, with three indices having moderate

442 correlations, whilst total mass < $2000 \mu \mathrm{m}$ was correlated with duration over 14 day

443 average discharge (D14AVd; Table 5).

444 Linear regression models developed for mass of deposited fines using the PC scores

445 explained between $8.78 \%$ and $53.92 \%$ of the variance in the mass of ingress (Table

446 6). For grains 1000- $2000 \mu \mathrm{m}$, discharge was the most influential predictor with the

447 model accounting for an additional $15.96 \%$ of the variance compared to turbidity

448 alone or $9.56 \%$ for turbidity and hydrology combined. The duration and magnitude of

449 high flow events were the most significant predictor variables ( $p=0.004$; Table 7$)$.

450 The mass of sediment deposited in the range $125-1000 \mu \mathrm{m}$ was strongly influenced

451 by turbidity with the model accounting for $45 \%$ of variation, $10 \%$ greater than for

452 discharge (Table 6). Both principal components were significant predictors with the

453 duration and magnitude of turbidity values being the dominant explanatory factors

454 (Table 7). The combination of discharge and turbidity parameters only accounted for

455 an additional $0.9 \%$ of variation and the final model developed using PC components

456 only characterised the turbidity series using PC1 and PC3 scores (Tables 6 \& 7).

457 For grains $<125 \mu \mathrm{m}$, mass of deposition was predominantly explained by turbidity, 458 with the model accounting for $53.52 \%$ of variation, $32.42 \%$ more than the discharge 459 model (Table 6). PC2 was the most significant predictor $(p=0.005)$ which 
460 characterised the magnitude of the turbidity regime (average conditions) and

461 duration of low turbidity events. When total mass $(<2000 \mu \mathrm{m})$ was considered,

462 turbidity was the most influential factor (37.15\%) and the magnitude and frequency of

463 high turbidity events were the dominant predictors $(p=0.047$; Tables $6 \& 7)$.

464 Similarly, the combined model (hydrological and turbidity) provided the best fit and

465 PC components that characterised the average, maximum and duration of low

466 turbidity elements of the regime were significant (Table 6). A summary of the multiple

467 linear regression models and the interpretations of the PC loadings for each of the 468 compartments are provided in Tables 6 and 7.

469 5. Discussion

470 This study investigated whether facets of discharge and turbidity time series can be

471 used to predict fine sediment ingress measured at multiple locations over several

472 months. It adopted a technique from ecohydrology, not previously applied to this

473 problem and uses robust and widely applicable parameters that can be readily

474 measured in the field. Discharge and turbidity have a relatively weak relationship

475 with each other and with mass of fine sediment ingress when individual facets of the

476 time series (e.g. magnitude or duration indices) are considered in isolation. In

477 contrast, the application of a well-established 'redundancy approach' and principal

478 component analysis enabled the fitting of multiple linear regression models, using

479 combinations of time series facets, that accounted for a larger proportion of variation

480 in the mass of fine sediment ingress. Turbidity, as a surrogate for suspended

481 sediment availability, exerted a greater influence than discharge. These results

482 indicate the potential of this method to be a useful tool for developing predictive

483 models of fine sediment ingress at scales that are relevant to sediment

484 management. Further testing and validation is required to evaluate the method's

485 applicability across different river types, flow and sediment regimes.

486

487

5.1 The relative role of discharge and turbidity in controlling fine sediment

488 ingress

489 When the individual regime facets (i.e. magnitude, duration, frequency) of turbidity

490 and discharge time series were considered, there were no significant associations

491 with the mass of infiltrated sediment. This indicates that, in isolation, individual flow

492 or sediment availability parameters are likely to be weak predictors of sediment 
ingress. The lack of apparent correlation between suspended sediment availability

494 and discharge also indicates that processes other than hydrological drivers may

495 affect changes in turbidity concentrations, including, for example, biotic processes

496 (Rice et al., 2012; Atkinson et al., 2017). Whatever the cause, temporal variations in

497 suspended sediment transport are important and are driven independently of

498 discharge.

499

500 In contrast, the application of linear regression using multiple facets of the discharge 501 and turbidity regimes yielded improved associations, indicating that it is not a single 502 element of discharge or turbidity that controls ingress, but a combination of multiple 503 facets. This also clearly highlights the advantages of employing principal component 504 analysis to distil time series datasets into a manageable number of unrelated 505 variables and so avoid overfitting models. The construction of linear regression 506 models using PC sample axis scores indicated that turbidity variables explained a 507 greater proportion of the statistical variance in deposition than discharge variables.

508 This suggests that the collection of high quality, turbidityntime series data should be 509 a priority in order to corroborate and develop the findings of this study, perhaps for 510 different flow conditions and different river typologies.

\subsection{Individual grain size associations with discharge and turbidity}

513 The strongest association in this study was between the ingress of grains $<125 \mu \mathrm{m}$

514 and turbidity, with the turbidity model accounting for $54 \%$ of the variation (with only

515 an additional $0.4 \%$ explained when discharge indices were incorporated). The

516 duration that turbidity was over 10 NTU was the most significant explanatory

517 variable. Grains in this size fraction, once in suspension, can be transported long

518 distances over extended time-periods because only low energy hydraulic conditions

519 are needed to entrain them and keep them in suspension (Lambert and Walling,

520 1988). Consequently, as the amount of time with turbidity levels are above 10 NTU

521 decreases, ingress of this size range may increase because fine sediment is

522 available for deposition. Discharge had the weakest association with this size

523 fraction (21\% variance explained) with rivers often acting as an effective

524 conveyance system for silt sized particles, irrespective of hydraulic energy. Grains in 525 the size fraction $125-1000 \mu \mathrm{m}$ were predominantly predicted by variables which 
526 characterised the magnitude of turbidity, with an explanatory power of $45 \%$, and

527 discharge indices provided little improvement (0.9\%) if incorporated.

528 The only grain size to be predominately associated with discharge was the size

529 fraction 1000-2000 $\mu \mathrm{m}$. The duration and magnitude of high discharge, accounted for

$53025 \%$ of the variability in ingress rates compared to $9 \%$ and $15 \%$ for the turbidity

531 and combined models, respectively. Grains in this size fraction are heavily reliant on

532 sufficient hydraulic stress for entrainment and suspension. Turbidity is not an

533 important driver because grains of this size are unlikely to remain in suspension and

534 be available for deposition during long baseflow periods (Rathburn and Wohl, 2003).

535 5.3 Principal component analysis as a tool to upscale the temporal controls on 536 fine sediment ingress

537 A significant gap in understanding and managing fine sediment ingress into river

538 beds is the difficulty of scaling up fine-scale process understanding, partly because

539 the key drivers are highly variable in space and time. Larger scale drivers, including

540 discharge and sediment availability, vary on synoptic to annual timescales, and may

541 provide an alternative means of modelling fine sediment deposition that is especially

542 pertinent to management questions. However, investigation of relations at these

543 larger scales has been limited by an absence of time series of sediment deposition

544 and sediment availability (Gray and Gartner, 2009). Using turbidity as a surrogate for

545 sediment concentration, longer, high-resolution datasets can now be routinely

546 collected (Loperfido et al., 2010), albeit subject to appropriate local calibration and

547 evaluation (Bilotta and Brazier, 2008).

548 Turbidity time series and gauged discharge data collected over a 14-week study 549 period on two rivers were used in this study to gain a better understanding of how 550 localised and temporal variations in discharge and turbidity influence the mass of 551 sediment deposited in a clean gravel framework. The methodological approach 552 employed highlights the potential value of undertaking principal component analysis 553 to characterise the overall facets of discharge and turbidity regimes that influence 554 fine sediment ingress and which can therefore inform large scale catchment sediment management practices. The approach is empirical, seeking site-specific relations between ingress, discharge and sediment availability. Its application and 
testing in additional field situations may yield wider generic understanding of

558 important controls at these scales.

559 Despite the potential utility of the approach, it is important to exercise caution when

560 employing data redundancy approaches, such as PCA, because they may reject

561 variables of importance due to the assumption that statistically dominant sources of

562 variability are the principal drivers of the association they are being used to describe

563 (Monk et al., 2007). Nevertheless, as applied here, the approach enables

564 characterisation of the key drivers of sediment ingress, improving our knowledge of

565 the time series and, by inference, processes that are relevant to sediment loading at

566 a scale appropriate for management strategies.

\section{6. Conclusion}

568 This study demonstrates, for the first time, that an adapted PCA-based data

569 redundancy reduction method (sensu Olden and Poff, 2003) can effectively be used

570 to identify the dominant facets of turbidity and discharge time series that influence

571 the mass of fine sediment ingress into gravel river beds. The results from this study

572 of two lowland rivers in England, indicate that discharge is weakly associated with

573 ingress rates and that localised turbidity variations explain a greater amount of the

574 variance in fine sediment deposition into clean gravels. In particular, the magnitude

575 facet of the turbidity regime are important for the ingress of grains in the size fraction

$576125-1000 \mu \mathrm{m}$, whilst magnitude and the duration of turbidity events below $10 \mathrm{NTU}$

577 are associated with grains in the size fraction $<125 \mu \mathrm{m}$.

578 The study highlights the need for additional research that simultaneously monitors 579 turbidity (or sediment concentrations), discharge and ingress rates during a range of

580 flow conditions. It is widely acknowledged that discharge during extreme flow periods 581 exerts a strong control over ingress rates (Frostick et al., 1984), but much less is 582 known about deposition rates and the principal drivers of this process during 583 baseflow conditions. Further understanding could be obtained by monitoring the 584 gradients of vertical and lateral hydrological exchange as a function of discharge, as 585 these exchanges exert a significant influence over ingress rates during baseflow 586 (Pettricrew et al., 2007).

\section{Acknowledgements}


KLM acknowledges the support of a Glendonbrook doctoral studentship and co-

590 funding from the Environment Agency to undertake this study. Thanks go to Matthew

591 Hill and James Smith who provided assistance with the fieldwork collection, Richard

592 Harland for providing technical and laboratory support and Samuel Dixon for help in

593 the collection of substrate for the sediment traps. The authors thank the comments of

594 two anonymous reviewers and the editor that have helped improved the clarity of the 595 study.

596

\section{References}

598 Abdi, H.,Williams, L.J., 2010. Principal component analysis. Wiley interdisciplinary 599 reviews: computational statistics 2, 433-459. doi:10.1002/wics.101.

600 Acreman, M.C., Ferguson, A.J.D., 2010. Environmental flows and the European 601 water framework directive. Freshwater Biol. 55, 32-48. doi: 10.1111/j.1365-

602 2427.2009.02181.

603 Albertson, L.K., Allen, D.C., 2015. Meta-analysis: abundance, behavior, and 604 hydraulic energy shape biotic effects on sediment transport in streams. Ecology 96, 605 1329-1339. doi: 10.1890/13-2138.

606 Arthington, A.H., Bunn, S.E., Poff, N.L., Naiman, R.J., 2006. The challenge of 607 providing environmental flow rules to sustain river ecosystems. Ecol. Appl. 16, 1311608 1318. doi: 10.1890/1051-0761(2006)016[1311:TCOPEF]2.0.CO;2.

609 Atkinson, C.L., Allen, D.C., Davis, L.Nickerson, Z.L., 2017. Incorporating 610 ecogeomorphic feedbacks to better understand resiliency in streams: A review and 611 directions forward. Geomorphology DOI: 10.1016/j.geomorph.2017.07.016.

612 Belmar, O., Velasco,J., Gutiérrez-Cánovas,C., Mellado-Díaz, A., Millán, A., Wood, 613 P.J., 2013. The influence of natural flow regimes on macroinvertebrate assemblages 614 in a semiarid Mediterranean basin. Ecohydrology 6, 363-379. doi:

615 10.1002/eco.1274.

616 Beschta, R.L., Jackson, W.L., 1979. The intrusion of fine sediments into a stable 617 gravel bed. Journal of the Fisheries Board of Canada 36, 204-210. doi:

618 bs/10.1139/f79-030\#.WT6DF8uGOUk.

619 Beschta, R.L., Jackson, W.L., Knoop, K.D., 1981. Sediment transport during a 620 controlled reservoir release. Water Resour Bull. 17, 635-641. doi: 10.1111/j.1752621 1688.1981.tb01270.x.

622 Bilotta, G.S. Brazier, R.E., 2008. Understanding the influence of suspended solids on 623 water quality and aquatic biota. Water Res. 42, 2849-2861. doi:

624 10.1016/j.watres.2008.03.018.

625 British Geological Survey, 2008. Digital Geological Map Data of Great Britain - 625k 
627 Brunke, M., 1999. Colmation and depth filtration within streambeds: retention of 628 particles in hyporheic interstices. International Review of Hydrobiology, 84, 99-117. 629 doi/abs/10.1002/iroh.199900014

630 Buffington, J.M., Montgomery, D.R., 1999. Effects of hydraulic roughness on surface 631 textures of gravel-bed rivers. Water Resour. Res. 35, 3507-3521. doi:

$63210.1029 / 1999$ WR900138.

633 Carling, P.A., 1984. Deposition of fine and coarse sand in an open-work gravel bed. 634 Can. J. Fish. Aquat. Sci. 41, 263-270. doi: abs/10.1139/f84-030\#.WT6Eb8uGOUk.

635 Carling, P.A., McCahon, C.P., 1987. Natural siltation of brown trout (Salmo trutta L.) 636 spawning gravels during low-flow conditions. In Craig, J.F. and Kemper, B.J. 637 Regulated streams: Advances in Ecology. Plenum Press: New York.

638 Collins, A.L., Naden, P.S., Sear, D.A., Jones, J.I., Foster, I.D., Morrow, K., 2011. 639 Sediment targets for informing river catchment management: international 640 experience and prospects. Hydrol. Process. 25, 2112-2129. doi: 10.1002/hyp. 7965.

641 Cooper, R.J., Outram, F.N., Hiscock, K.M., 2016. Diel turbidity cycles in a headwater 642 stream: evidence of nocturnal bioturbation?. J. Soils Sediments, 16, 1815-1824. doi: 643 10.1007/s11368-016-1372-y.

644 Dean, W. E., 1974. Determination of carbonate and organic matter in calcareous 645 sediments and sedimentary rocks by loss on ignition; comparison with other 646 methods. Journal of Sedimentary Research 44, 242-248.

647 Diplas, P., Parker, G., 1992. Deposition and removal of fines in gravel-bed streams. 648 In. Billi, P., D. Hey, C.R. Thorne and P. Tacconi. Dynamics of gravel-bed rivers, John 649 Wiley and Sons: Chichester.

650 Einstein, H.A., 1968. Deposition of suspended particles in a gravel bed. Journal of 651 the Hydraulics Division, 94, 1197-1206.

652 Faller, M., Harvey, G.L., Henshaw, A.J., Bertoldi, W., Bruno, M.C., England, J., 2016. 653 River bank burrowing by invasive crayfish: Spatial distribution, biophysical controls 654 and biogeomorphic significance. Sci. Total Environ. 569, 1190-1200.

655 Franssen, J., Lapointe, M., Magnan, P., 2014., Geomorphic controls on fine 656 sediment reinfiltration into salmonid spawning gravels and the implications for 657 spawning habitat rehabilitation. Geomorphology, 211, 11-21. doi:

658 10.1016/j.geomorph.2013.12.019.

659 Frings, R.M., Kleinhans, M.G., Vollmer, S., 2008. Discriminating between pore 660 filling load and bed-structure load: a new porosity-based method, exemplified for the 661 river Rhine. Sedimentology 55, 1571-1593. doi: 10.1111/j.1365-3091.2008.00958.x. 
662 Frostick, L.E., Lucas, P.M., Reid, I., 1984. The infiltration of fine matrices into coarse663 grained alluvial sediments and its implications for stratigraphical interpretation. J. 664 Geol. Society. 141, 955-965. doi: 10.1144/gsjgs.141.6.0955.

665 Gibson, S., Abraham, D., Heath, R., Schoellhamer, D., 2009. Bridging process 666 threshold for sediment infiltrating into a coarse substrate. J. Geotech. Geoenviron. 667 136, 402-406. doi: 10.1061/\%28ASCE\%29GT.1943-5606.0000219.

668 Gray, J.R., Gartner, J.W., 2009. Technological advances in suspended-sediment 669 surrogate monitoring. Water Resour. Res. 45,. Doi: 10.1029/2008WR007063.

670 Harvey, G.L., Henshaw, A.J., Moorhouse, T.P., Clifford, N.J., Holah, H., Grey, J., 671 Macdonald, D.W., 2014. Invasive crayfish as drivers of fine sediment dynamics in 672 rivers: field and laboratory evidence. Earth Surf. Processes. 39, 259-271. Doi: 673 10.1002/esp.3486.

674 Heppell, C.M., Wharton, G., Cotton, J.A.C., Bass, J.A.B., Roberts, S.E., 2009. 675 Sediment storage in the shallow hyporheic of lowland vegetated river reaches. 676 Hydrol. Process., 23, 2239-2251. doi: 10.1002/hyp.7283.

677 Jackson, H.M., Gibbins, C.N., Soulsby, C., 2007. Role of discharge and temperature 678 variation in determining invertebrate community structure in a regulated river. River 679 Res. Appl., 23, 651-669. doi: 10.1002/rra.1006.

680 Jolliffe, I.T., 1986. Principal Component Analysis, Springer-Verlag : New York.

681 Jones, J.I., Collins, A.L., Naden, P.S., Sear, D.A., 2012a. The relationship between 682 fine sediment and macrophytes in rivers. River Res. Appl., 28, 1006-1018. doi: $68310.1002 /$ rra.1486.

684 Jones, J.I., Murphy, J.F., Collins, A.L., Sear, d.A., Naden, P.S., Armitage, P.D., 685 2012b. The impact of fine sediment on macro-invertebrates. River Res. Appl., 28, 686 1055-1071. doi: 10.1002/rra.1516.

687 Jones, J.I., Duerdoth, C.P., Collins, A.L., Naden, P.S., Sear, D.A., 2014. Interactions 688 between diatoms and fine sediment. Hydrol. Process., 28, 1226-1237. doi: 689 10.1002/hyp.9671.

690 Kemp, P., Sear, D.A., Collins, A., Naden, P. Jones, I., 2011.The impacts of fine 691 sediment on riverine fish. Hydrol. Process., 25, 1800-1821. doi: 10.1002/hyp.7940.

692 Komac, M., 2006. A landslide susceptibility model using the analytical hierarchy 693 process method and multivariate statistics in perialpine 694 Slovenia. Geomorphology, 74, 17-28.

695 Lambert, C.P., Walling, D.E., 1988. Measurement of channel storage of suspended 696 sediment in a gravel-bed river. Catena, 15, 65-80. doi: 10.1016/0341-

697 8162(88)90017-3. 

Interactive effects of substrate sand and silt contents, redd-scale hydraulic gradients, and interstitial velocities on egg-to-emergence survival of Atlantic salmon (Salmo salar). Can. J. Fish. Aquat. Sci., 61, 2271-2277. doi: 10.1139/f04-236.

702 Loperfido, J.V., Just, C.L., Papanicolaou, A.N., Schnoor, J.L. 2010. In situ sensing to understand diel turbidity cycles, suspended solids, and nutrient transport in Clear 704 Creek, lowa. Water Resour. Res. 46. doi: 10.1029/2009WR008293.

705

706

707

708

709

710

711

712

713

714

715

716

717

718

719

720

721

722

723

724

725

726

727

728

729

730

731

732

Mathers, K.L., Wood, P.J., 2016. Fine sediment deposition and interstitial flow effects on macroinvertebrate community composition within riffle heads and tails. Hydrobiologia, 776, 147-160. doi: 10.1007/s10750-016-2748-0.

McNeil, W.J., Ahnell, W.H., 1964. Success of pink salmon spawning relative to size of spawning bed materials (No. 157). US Department of Interior, Fish and Wildlife Service.

Monk, W.A., Wood, P.J., Hannah, D.M., Wilson, D.A., 2007. Selection of river flow indices for the assessment of hydroecological change. River Res. Appl. 23 , 113122. doi: $10.1002 /$ rra.964.

Monk, W.A., Wood, P.J., Hannah, D.M., Wilson, D.A., Extence, C.A., Chadd, R.P., 2006. Flow variability and macroinvertebrate community response within riverine systems. River Res. Appl. 22, 595-615. doi: 10.1002/rra.933.

Mustonen, K.R., Mykrä, H., Marttila, H., Haghighi, A.T., Kløve, B., Aroviita, J., Veijalainen, N., Sippel, K., Muotka, T., 2016. Defining the natural flow regimes of boreal rivers: relationship with benthic macroinvertebrate communities. Freshwater Sci. 35, 559-572. doi: 10.1086/685104.

Naden, P.S., Murphy, J.F., Old, G.H., Newman, J., Scarlett, P., Harman, M., Duerdoth, C.P., Hawczak, A., Pretty, J.L., Arnold, A., Laizé, C., 2016. Understanding the controls on deposited fine sediment in the streams of agricultural catchments. Sci. Total Environ. 547, 366-381. doi: 10.1016/j.scitotenv.2015.12.079.

National River Flow Archive, 2017. Available at: https://nrfa.ceh.ac.uk/ [Access Date: 15 Dec 2017].

Olden, J.D., Naiman, R.J., 2010. Incorporating thermal regimes into environmental flows assessments: modifying dam operations to restore freshwater ecosystem integrity. Freshwater Biol. 55, 86-107. doi: 10.1111/j.1365-2427.2009.02179.x.

Olden, J.D., Poff, N.L., 2003. Redundancy and the choice of hydrologic indices for characterizing streamflow regimes. River Res. Appl. 19,101-121. doi:

$10.1002 /$ rra.700. 
734 invertebrates to fine sediment removal in two chalk rivers. Fund. Appl. Limnology 18, 283-288. doi: 10.1127/1863-9135/2012/0388.

736 Petticrew, E. L., Krein, A., Walling, D.E., 2007. Evaluating fine sediment mobilization 737 and storage in a gravel-bed river using controlled reservoir releases. Hydrol.

738 Process. 21, 198-210. doi: 10.1002/hyp.6183.

739 Petts, G.E., 1984. Sedimentation within a regulated river. Earth Surf, Proc. Land. 9, 740 125-134. doi: 10.1002/esp.3290090204.

741 Petts, G.E., 1988. Accumulation of fine sediment within substrate gravels along two 742 regulated rivers, UK. Regul. River. 2, 141-153. doi: 10.1002/rrr.3450020208.

743 Poff, N., 1996. A hydrogeography of unregulated streams in the United States and 744 an examination of scale-dependence in some hydrological descriptors. Freshwater 745 Biol. 36, 71-79. doi: 10.1046/j.1365-2427.1996.00073.x.

746 Poff, N.L., Allan, J.D., Bain, M.B., Karr, J.R., Prestegaard, K.L., Richter, B.D., 747 Sparks, R.E., Stromberg, J.C., 1997. The natural flow regime. BioScience, 47, 769748784.

749 Poff, N.L., Zimmerman, J.K., 2010. Ecological responses to altered flow regimes: a 750 literature review to inform the science and management of environmental flows.

$\nmid 51$ Freshwater Biol. 55, 194-205. doi: 10.1111/j.1365-2427.2009.02272.x.

752 R Core Team (2017) R: A language and environment for statistical computing. R 753 foundation for statistical computing, Vienna, Austria. URL: http://www.R-project.org/.

754 Rathburn, S., Wohl, E., 2003. Predicting fine sediment dynamics along a pool-riffle 755 mountain channel. Geomorphology 55, 111-124. doi: 10.1016/S0169-

756 555X(03)00135-1.

757 Relyea, C.D., Minshall, G.W., Danehy, R.J., 2012. Development and validation of an 758 aquatic fine sediment biotic index. Environ. Manage. 49, 242-252. doi:

759 10.1007/s00267-011-9784-3.

760 Rice, S. P., Johnson, M.F., Reid, I., 2012. Animals and the geomorphology of gravel761 bed rivers. In Church, M., Biron, P.M., Roy, A.J., (Eds) Gravel-bed Rivers:

762 Processes, Tools, Environments, John Wiley \& Sons: Chichester.

763 Rice, S.P., Johnson, M.F., Extence, C., Reeds, J., Longstaff, H., 2014. Diel patterns 764 of suspended sediment flux and the zoogeomorphic agency of invasive crayfish.

765 Cuadernos de Investigación Geográfic. 40, 7-27.

766 Rice, S.P., Johnson, M.F., Mathers, K., Reeds, J., Extence, C., 2016. The 767 importance of biotic entrainment for base flow fluvial sediment transport. J. Geophys. 768 Res. 121, 890-906. doi: 10.1002/2015JF003726. 
769 Richter, B., Baumgartner, J., Wigington, R., Braun, D., 1997. How much water does

770 a river need?. Freshwater Biol., 37, 231-249. doi: 10.1046/j.1365-

771 2427.1997.00153.x.

772 Richter, B.D., Baumgartner, J.V., Powell, J., Braun, D.P., 1996. A method for

773 assessing hydrologic alteration within ecosystems. Conserv. Biol. 10, 1163-1174.

774 doi: 10.1046/j.1523-1739.1996.10041163.x.

775 Sear, D.A., 1993. Fine sediment infiltration into gravel spawning beds within a 776 regulated river experiencing floods: ecological implications for salmonids. Regul.

777 River., 8, 373-390. doi: 10.1002/rrr.3450080407.

778 Singh, P.K., Kumar, V., Purohit, R.C., Kothari, M., Dashora, P.K., 2009. Application 779 of principal component analysis in grouping geomorphic parameters for hydrologic 780 modelling. Water Resour. Man. 23, 325-339.

781 Statzner, B., 2012. Geomorphological implications of engineering bed sediments by 782 lotic animals. Geomorphology 157-158, 49-65. doi:10.1016/j.geomorph.2011.03.022.

783 Venables, W. N., Ripley, B. D., 2002. Modern Applied Statistics with S. Fourth 784 Edition. Springer, New York. ISBN 0-387-95457-0

785 Walling, D.E., Fang, D., 2003. Recent trends in the suspended sediment loads of the 786 world's rivers. Global Planet. Change 39, 111-126. doi: 10.1016/S0921-

787 8181(03)00020-1.

788

Wharfe, D. M., Hardie, S.A., Uytendaal, A.R., Bobbi, C.J., Barmuta, L.A., 2014. The

789 ecology of rivers with contrasting flow regimes: identifying indicators for setting

790 environmental flows. Freshwater Biol. 59, 2064-2080. doi: 10.1111/fwb.124.

791

White, J. C., Hannah, D.M., House, A., Beatson, S.J.V., Martin, A., Wood, P.J., 792 2017. Macroinvertebrate responses to flow and stream temperature variability across 793 regulated and non-regulated rivers. Ecohydrology 10, e1773. doi: 10.1002/eco.1773.

794 Wohl, E., Bledsoe, B.P., Jacobson, R.B., Poff, N.L., Rathburn, S.L., Walters, D.M., 795 Wilcox, A.C., 2015. The natural sediment regime in rivers: broadening the foundation 796 for ecosystem management. BioScience 65, 358-371. doi: 10.1093/biosci/biv002.

798

Wolman, M.G., 1954. A method of sampling coarse river-bed material. EOS,

799

800 Transactions American Geophysical Union 35, 951-956. doi: 10.1029/TR035i006p00951

801

Wood, P.J., Armitage, P.D., 1999. Sediment deposition in a small lowland stream802 management implications. Regul. River., 15, 199-210. doi: 10.1002/(SICI)10991646(199901/06)15:1/3<199::AID-RRR531>3.0.CO;2-0.

803 Worrall, T.P., Dunbar, M.J., Extence, C.A., Laize, C.L., Monk, W.A., Wood, P.J., 804 2014. The identification of hydrological indices for the characterization of 
805 macroinvertebrate community response to flow regime variability. Hydrolog. Sci. J., 80659, 645-658.

807

808

809

810

811

812

813

814

815

816

817

818

819

820

821

822

823

824

825

826

827

828

829

830

831 


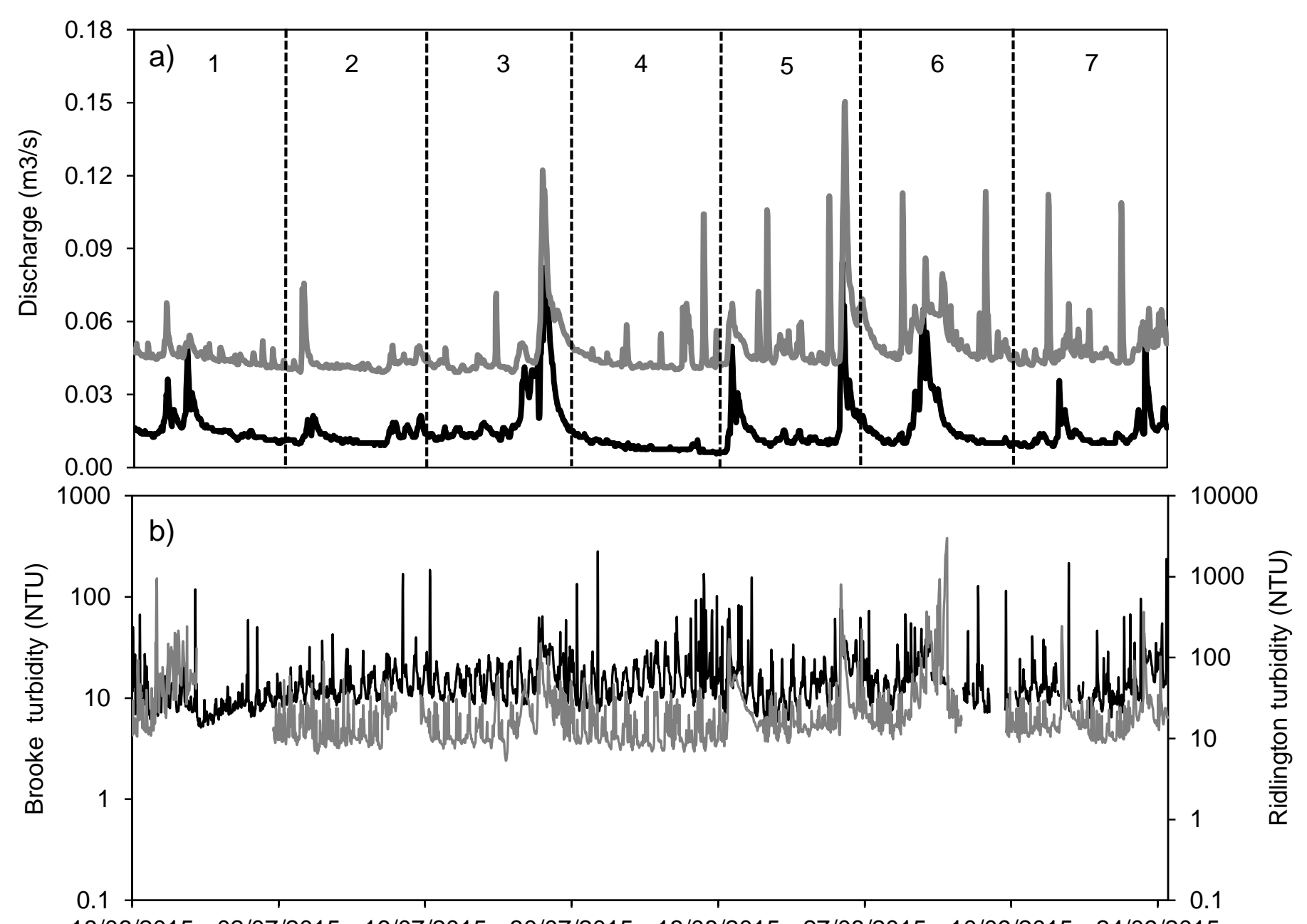

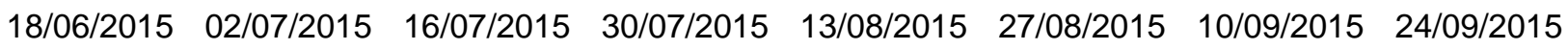

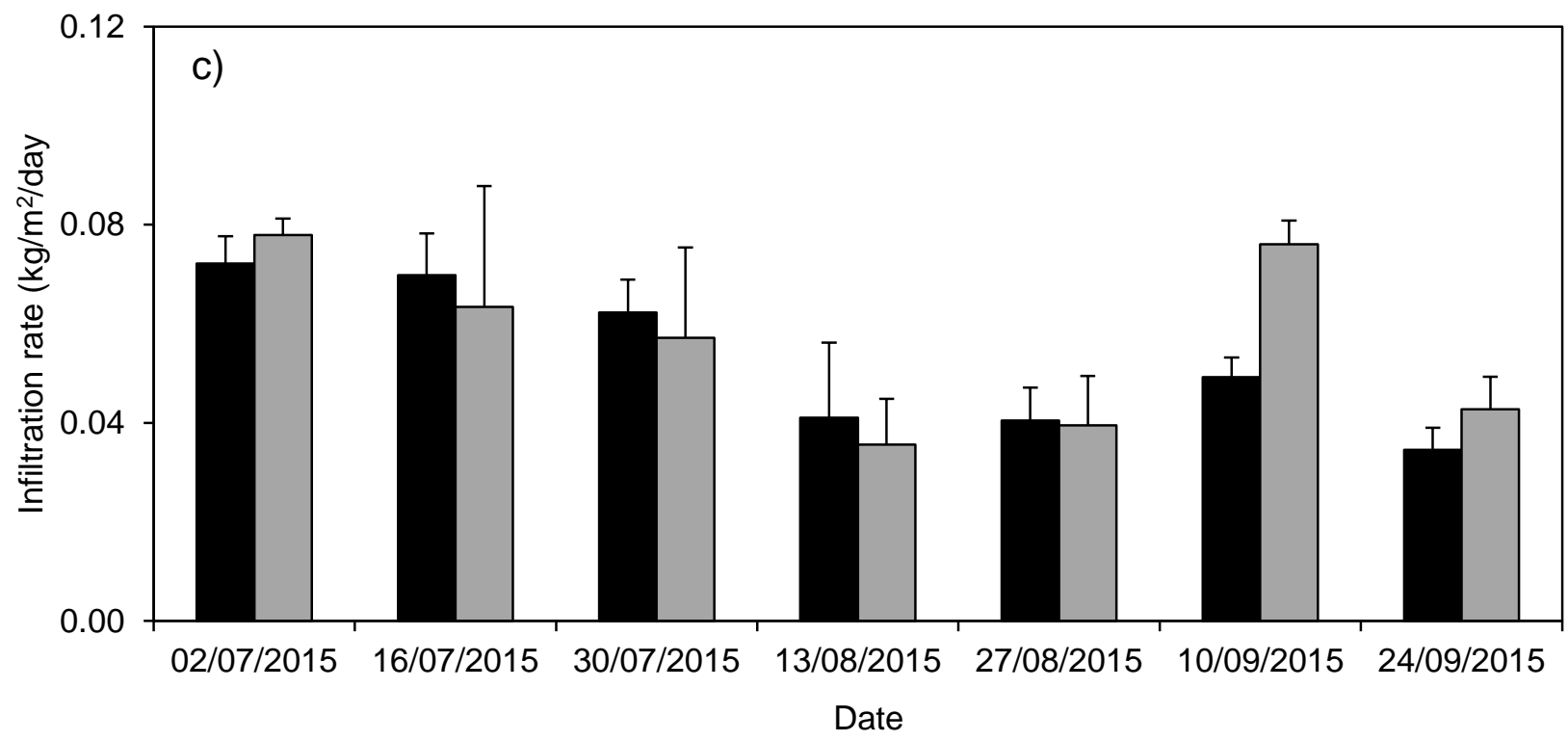

Figure 1. 


$$
\text { MAthin }
$$



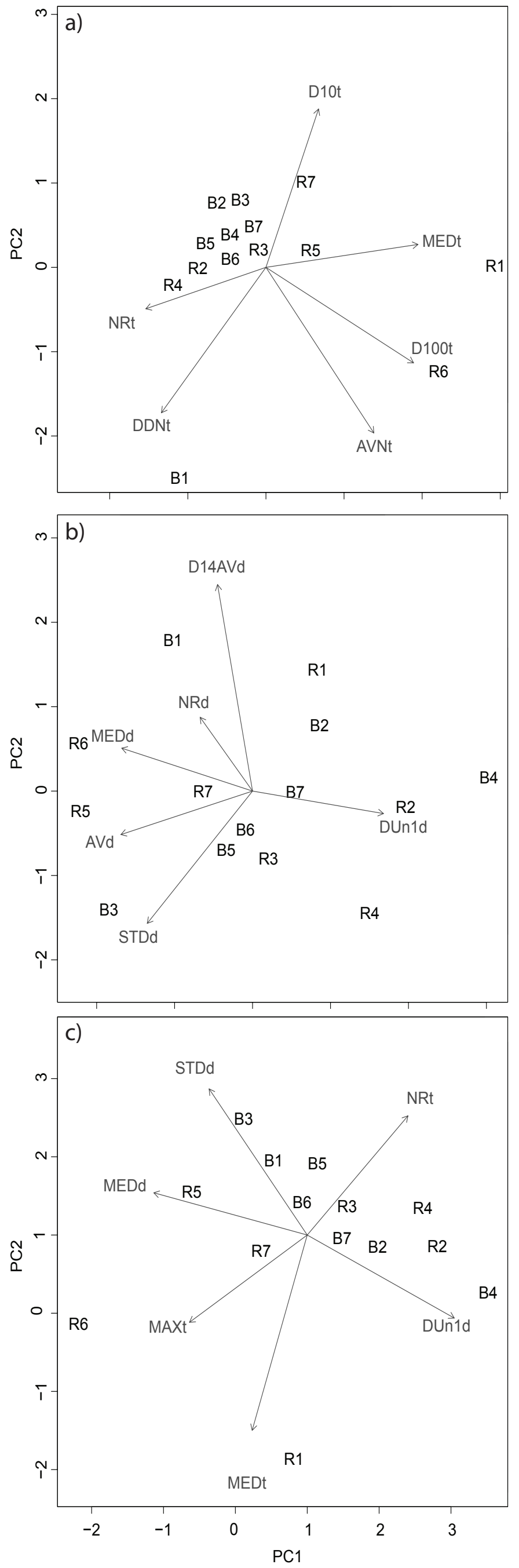
Table 1. Metrics of bed material grain size distributions, including fine sediment measures, for the study reaches

\begin{tabular}{|c|c|c|}
\hline Grain size characteristic & Brooke & Ridlington \\
\hline \multicolumn{3}{|l|}{ Surface $^{a}$} \\
\hline $\mathrm{D}_{16}(\mathrm{~mm})$ & 4.2 & 6.0 \\
\hline $\mathrm{D}_{50}(\mathrm{~mm})$ & 13.4 & 32.0 \\
\hline $\mathrm{D}_{84}(\mathrm{~mm})$ & 20.6 & 64.0 \\
\hline Mass < $4 \mathrm{~mm}(\%)$ & 4.3 & 3.9 \\
\hline \multicolumn{3}{|l|}{ Subsurface ${ }^{b}$} \\
\hline $\mathrm{D}_{16}(\mathrm{~mm})$ & 1.4 & 0.8 \\
\hline $\mathrm{D}_{50}(\mathrm{~mm})$ & 9.1 & 7.8 \\
\hline $\mathrm{D}_{84}(\mathrm{~mm})$ & 24.2 & 36.3 \\
\hline Mass < 2mm (\%) & 20.0 & 28.8 \\
\hline
\end{tabular}


Table 2. Summary of turbidity and flow indices calculated in this study.

\begin{tabular}{|c|c|c|c|c|c|}
\hline $\begin{array}{c}\text { Facet of the } \\
\text { turbidity } \\
\text { regime }\end{array}$ & $\begin{array}{c}\text { Turbidit } \\
y \\
\text { indices }\end{array}$ & Description & $\begin{array}{c}\text { Facet of the } \\
\text { discharge } \\
\text { regime }\end{array}$ & $\begin{array}{c}\text { Dischar } \\
\text { ge } \\
\text { indices }\end{array}$ & Description \\
\hline Magnitude & MAXt & Maximum turbidity & Magnitude & MAXd & Maximum discharge \\
\hline Magnitude & MINt & Minimum turbidity & Magnitude & $\mathrm{MINd}$ & Minimum discharge \\
\hline Magnitude & RANt & Turbidity range & Magnitude & RANd & Discharge range \\
\hline Magnitude & STDt & Standard deviation of turbidity & Magnitude & STDd & Standard deviation of discharge \\
\hline Magnitude & $\mathrm{AVt}$ & 14 day average turbidity value & Magnitude & $A \vee d$ & 14 day average discharge \\
\hline Magnitude & MEDt & Median turbidity value & Magnitude & MEDd & Median discharge \\
\hline Duration & D10t & Duration over 10 NTU & Duration & D1d & Duration over 0.1 (z standardised score) \\
\hline Duration & $\mathrm{D} 20 \mathrm{t}$ & Duration over 20 NTU & Duration & $\mathrm{D} 2 \mathrm{~d}$ & Duration over 0.2 (z standardised score) \\
\hline Duration & D50t & Duration over 50 NTU & Duration & DUn1d & Duration under - 0.1 (z standardised score) \\
\hline Duration & D100t & Duration over 100 NTU & Duration & DUn2d & Duration over - 0.2 (z standardised score) \\
\hline Duration & DU10t & Duration under 10 NTU & Duration & D14AVd & Duration over 14 day average discharge \\
\hline Duration & D14AVt & Duration over 14 day average turbidity value & Duration & DTAVd & Duration over total average discharge \\
\hline Duration & DTAVt & Duration over total average turbidity value & Frequency & NPTAVd & Number of peaks over total average discharge \\
\hline Rate of change & PERt & Periodicity & Rate of change & NRd & Number of rises in discharge series \\
\hline Magnitude & AVNt & Average night turbidity value & & & \\
\hline Magnitude & AVDt & Average day turbidity value & & & \\
\hline Magnitude & DDNt & Average difference in day and night turbidity & & & \\
\hline Frequency & NP20t & Number of peaks over 20 NTU & & & \\
\hline Frequency & NP50t & Number of peaks over 50 NTU & & & \\
\hline Frequency & NP100t & Number of peaks over 100 NTU & & & \\
\hline Rate of change & NRt & Number of rises in turbidity series & & & \\
\hline
\end{tabular}


Table 3. Summary of the percentage variability explained on axes 1-4 for each of the six sets of variables

\begin{tabular}{lccccc}
\hline & \multicolumn{3}{c}{$\begin{array}{l}\text { Principal component (\% variance } \\
\text { explained) }\end{array}$} & & \multirow{2}{*}{ Total (\%) } \\
\cline { 2 - 5 } & $\mathbf{1}$ & $\mathbf{2}$ & $\mathbf{3}$ & $\mathbf{4}$ & \\
\hline All turbidity & 48.39 & 20.06 & 11.47 & 7.15 & 87.07 \\
Reduced turbidity & 52.48 & 25.59 & 11.84 & 8.74 & 98.65 \\
All hydrological & 66.68 & 15.5 & 11.45 & 4.04 & 97.67 \\
Reduced hydrological & 55.41 & 19.87 & 16.30 & 6.60 & 98.18 \\
Turbidity and hydrological combined & 39.08 & 21.23 & 13.06 & 8.51 & 81.88 \\
Reduced turbidity and hydrological & 48.19 & 27.37 & 16.93 & 4.9 & 97.39 \\
\hline
\end{tabular}

Table 4 .Spearman's rank correlations for all discharge (standardised) and turbidity indices (only those with a moderate correlation stronger than $r_{s}>0.5$ are presented).

\begin{tabular}{lll}
\hline Discharge index & Turbidity index & p value \\
\hline MINd & MAXt & $0.546^{*}$ \\
MINd & RANt & $0.546^{*}$ \\
MEDd & MAXt & $0.596^{*}$ \\
MEDd & RANt & $0.596^{*}$ \\
MEDd & AVt & $0.595^{*}$ \\
MEDd & D100t & 0.519 \\
MEDd & STDt & 0.522 \\
NPTAVd & MINt & $0.504^{*}$ \\
NPTAVd & NRt & -0.613 \\
D14AVd & MAXt & $0.709^{* * *}$ \\
D14AVd & RANt & $0.709^{* * *}$ \\
D14AVd & AVt & $0.630^{*}$ \\
D14AVd & D50t & $0.570^{* *}$ \\
D14AVd & D100t & $0.720^{*}$ \\
D14AVd & AVNt & 0.522 \\
D14AVd & NP50t & $0.541^{*}$ \\
D14AVd & NP100t & $0.782^{* * *}$ \\
D14AVd & STDt & $0.674^{*}$ \\
D14AVd & D14AVt & $-0.617^{*}$ \\
DUn1d & MAXt & -0.525 \\
DUN2d & MAXt & $-0.560^{*}$ \\
DUN2d & $-0.560^{*}$ \\
DTAVd & RANt & 0.530 \\
\hline$*$ &
\end{tabular}

${ }^{*} p \leq 0.05,{ }^{* *} P \leq 0.01,{ }^{* * *} p \leq 0.005$ 
Table 5. Spearman's rank correlations for discharge (standardised) and turbidity indices and ingress grain size characteristics ( $\mathrm{g}$; only those with a moderate correlation stronger than $r_{s}>0.5$ are presented).

\begin{tabular}{lll}
\hline Grain size & Index & p value \\
\hline Total mass $<2000 \mu \mathrm{m}$ & D14AVd & $0.566^{*}$ \\
$1000-2000 \mu \mathrm{m}$ & NP100t & $0.592^{*}$ \\
$1000-2000 \mu \mathrm{m}$ & AVNt & $0.560 *$ \\
$1000-2000 \mu \mathrm{m}$ & D100t & 0.531 \\
$1000-2000 \mu \mathrm{m}$ & D14AVd & $0.617^{*}$ \\
\hline
\end{tabular}

${ }^{*} \mathrm{p} \leq 0.05,{ }^{* *} \mathrm{P} \leq 0.01,{ }^{* * *} \mathrm{p} \leq 0.005$ 
Table 6. Summary of multiple linear regression models fitted to ingress rates using PC scores from turbidity, discharge and turbidity + discharge datasets (reduced). ${ }^{*} p \leq 0.05,{ }^{* *} P \leq 0.01,{ }^{* * *} p \leq 0.005$.

\begin{tabular}{|c|c|c|c|c|c|c|}
\hline Datasets & Predictor & Adjusted $\mathbf{R}^{2}$ & $\mathbf{F}$ & Model $p$ value & \multicolumn{2}{|c|}{ Variable $p$ value } \\
\hline \multicolumn{7}{|l|}{ Total mass $<2000 \mu \mathrm{m}$} \\
\hline Turbidity & $P C 1+P C 2$ & 37.15 & 4.48 & 0.03 * & PC1 0.047 & PC2 0.053 \\
\hline Discharge & PC2 & 30.03 & 6.58 & 0.03 * & & \\
\hline $\begin{array}{c}\text { Turbidity + Discharge } \\
\text { 1000- } 2000 \mu \mathrm{m}\end{array}$ & $P C 1+P C 3$ & 32.39 & 4.11 & 0.05 * & PC1 0.0394 & PC3 0.125 \\
\hline Turbidity & PC1 & 8.78 & 2.25 & 0.16 & & \\
\hline Discharge & PC2 & 24.74 & 5.27 & 0.04 * & & \\
\hline $\begin{array}{c}\text { Turbidity + Discharge } \\
125-1000 \mu \mathrm{m}\end{array}$ & \multicolumn{5}{|c|}{$125-1000 \mu \mathrm{m}$} & \\
\hline Turbidity & $P C 1+P C 2$ & 45.00 & 6.31 & 0.02 * & PC1 0.020 & PC2 0.043 \\
\hline Discharge & $P C 1+P C 2$ & 35.00 & 4.58 & 0.03 * & PC1 0.106 & PC2 0.032 \\
\hline $\begin{array}{c}\text { Turbidity + Discharge } \\
<\mathbf{1 2 5 \mu \mathrm { m }}\end{array}$ & $P C 1+P C 3$ & 45.90 & 6.52 & 0.01 * & PC1 0.107 & PC3 0.150 \\
\hline Turbidity & $\mathrm{PC} 1+\mathrm{PC} 2$ & 53.52 & 8.49 & $0.01 *$ & PC1 0.056 & PC2 0.005 \\
\hline Discharge & PC2 & 20.90 & 4.43 & 0.06 & & \\
\hline Turbidity + Discharge & $P C 1+P C 3$ & 53.92 & 8.61 & 0.01 * & PC1 0.020 & PC3 0.010 \\
\hline
\end{tabular}


Table 7. Principal component loadings for the variables within the principle components analysis.

\begin{tabular}{|c|c|c|c|c|c|c|}
\hline \multirow[b]{2}{*}{ Dataset } & \multicolumn{2}{|r|}{ PC1 } & \multicolumn{2}{|r|}{ PC2 } & \multicolumn{2}{|c|}{ PC3 } \\
\hline & $\begin{array}{l}\text { Variable } \\
\text { loadings }\end{array}$ & Interpretation & $\begin{array}{l}\text { Variable } \\
\text { loadings }\end{array}$ & Interpretation & $\begin{array}{l}\text { Variable } \\
\text { loadings }\end{array}$ & Interpretation \\
\hline Turbidity & $\begin{array}{l}\text { MEDt }(0.52) \\
\text { D100t }(0.51) \\
\text { NRt }(-0.41)\end{array}$ & $\begin{array}{l}\text { Magnitude, duration } \\
\text { and frequency of } \\
\text { turbidity events (high) }\end{array}$ & $\begin{array}{l}\text { D10t }(0.56) \\
\text { AVNt }(-0.50) \\
\text { DDNt }(-0.51)\end{array}$ & $\begin{array}{l}\text { Duration of low turbidity } \\
\text { events and absolute value } \\
\text { of average turbidity } \\
\text { conditions }\end{array}$ & & \\
\hline Discharge & $\begin{array}{l}\text { MEDd }(-0.47) \\
\text { DUn1d }(0.47) \\
\text { AVd }(-0.47)\end{array}$ & $\begin{array}{l}\text { Duration of low } \\
\text { discharge events and } \\
\text { average discharge }\end{array}$ & $\begin{array}{l}\text { D14AVd }(0.71), \\
\text { STDd }(-0.55), \\
\text { NRd }(0.33)\end{array}$ & $\begin{array}{l}\text { Duration above average } \\
\text { discharge conditions and } \\
\text { magnitude of discharge }\end{array}$ & & \\
\hline $\begin{array}{c}\text { Turbidity } \\
\& \\
\text { discharge }\end{array}$ & $\begin{array}{l}\text { AVt }(-0.55) \\
\text { MAXt }(-0.51)\end{array}$ & $\begin{array}{l}\text { Average and extreme } \\
\text { turbidity conditions }\end{array}$ & $\begin{array}{l}\text { STDd }(0.62) \text {, } \\
\text { DUn1d }(-0.57) \text {, } \\
\text { MEDt }(-0.44)\end{array}$ & $\begin{array}{l}\text { Magnitude of discharge } \\
\text { and turbidity, duration of } \\
\text { low discharge conditions }\end{array}$ & DU10t $(-0.66)$ & $\begin{array}{l}\text { Duration under low } \\
\text { turbidity threshold }\end{array}$ \\
\hline
\end{tabular}




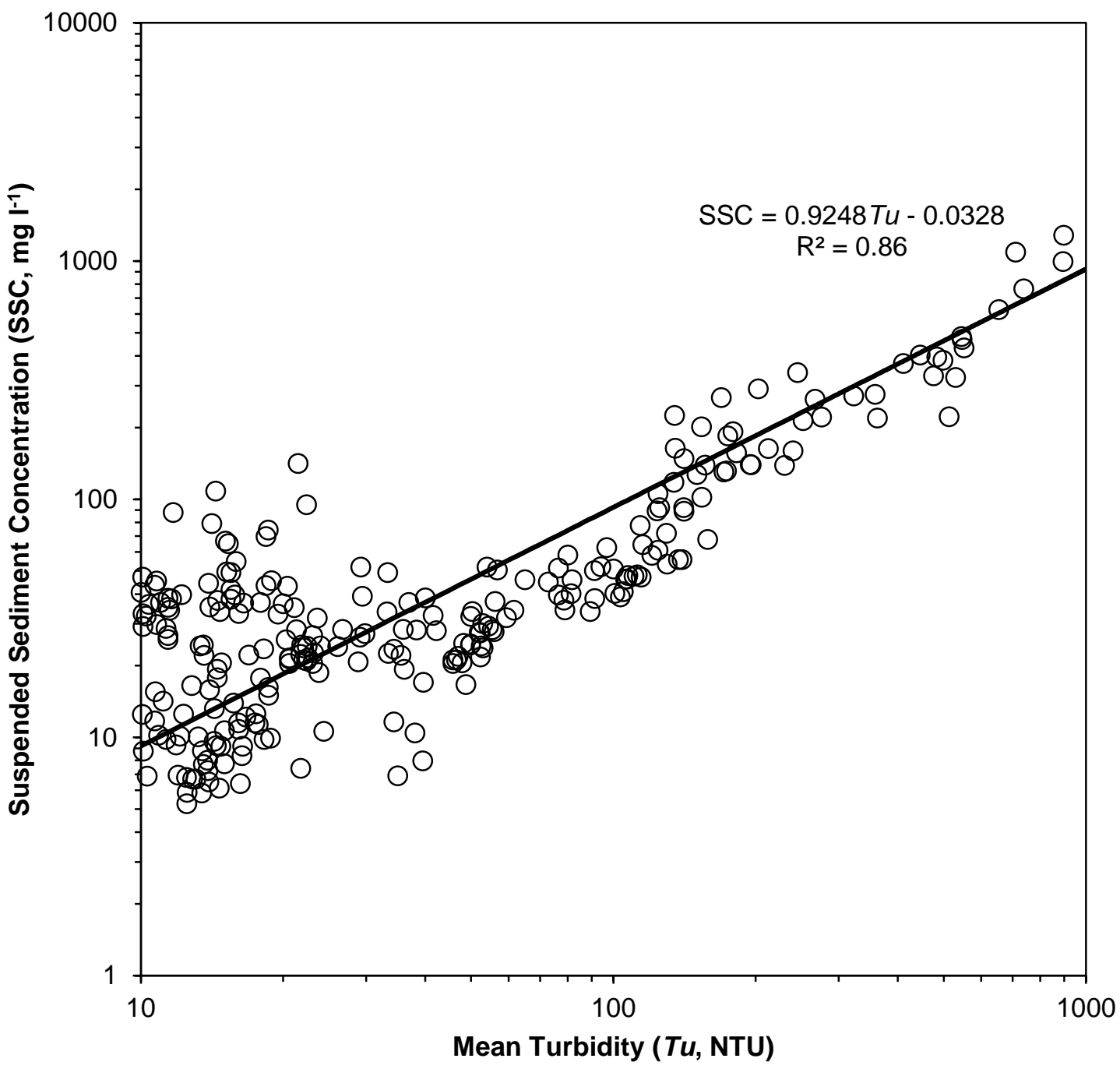

Figure S1. Relation between measure turbidity and concurrently suspended sediment concentrations from Brooke and Ridlington field sites $(n=299)$. 